\title{
KOMUNIKASI INTERNAL DALAM MEMBANGUN KOHESIVITAS KELOMPOK PEGIAT WISATA DI KABUPATEN PANGANDARAN
}

\author{
Iriana Bakti, Suwandi Sumartias, Trie Damayanti, dan Aat Ruchiat Nugraha
}

Fakultas Ilmu Komunikasi, Universitas Padjadjaran, Jl. Raya Bandung-Sumedang KM. 21 Jatinangor, 456363

E-mail: iriana.bakti@unpad.ac.id

\begin{abstract}
ABSTRAK. Perkembangan komunikasi internal dalam suatu organisasi menjadi sangat penting terutama dalam membangun kerjasama kelompok. Salah satu komunitas yang fokus mengembangkan aspek pariwisata di Pangandaran yaitu Kelompok Penggerak Pariwisata (Kompepar). Komunitas ini memiliki potensi yang cukup besara dalam melakukan koordinasi dan kerjasama untuk mewujudkan visi Pangandaran sebagai destinasi wisata dunia karena memiliki latarbelakang profesi anggotanya yang berbeda. Penelitian ini bertujuan untuk menjelaskan aktivitas komunikasi internal kompepar dalam mengembangkan objek wisata berbasis alam dan kearifan lokal di Kabupaten Pangandaran. Metode yang digunakan dalam penelitian ini adalah deskrtiptif dengan sifat data kuantitatif berdasarkan pada teknik pengumpulan data melalui observasi dan kuesioner yang dibagikan kepada responden secara acak sederhana. Hasil penelitian menunjukkan bahwa intensitas komunikasi internal dalam bentuk pertemuan rutin diantara anggota kompepar cukup tinggi untuk berbagi informasi dalam upaya meningkatkan pengetahuan, menjalin relasi, dan membangun kesadaran bagi para pengelola pelaku usaha pariwisata agar berpartisipasi aktif dalam kegiatan kepariwisataaan di Kabupaten Pangandaran. Sedangkan aspek kohesivitas di kalangan anggota kompepar di Kabupaten Pangandaran dapat dikategorikan tinggi dalam membangun kesamaan pandangan, meningkatkan wawasan, membagi tugas, dan melakukan kerja sama untuk mencapai tujuan kelompok.
\end{abstract}

Kata kunci: komunikasi internal; kohesivitas; kompepar; pembagian tugas; kerjasama

\section{INTERNAL COMMUNICATION IN DEVELOPING THE COHESIVITY OF TOURISM GROUP IN KABUPATEN PANGANDARAN}

\begin{abstract}
The development of internal communication within an organization becomes very important especially in building group collaboration. One community that focuses on developing aspects of tourism in Pangandaran is the Tourism Driving Group (Kompepar). This community has considerable potential in coordinating and collaborating to realize the vision. Pangandaran as a world tourist destination because it has a different member professional background. This study aims to explain the internal communication activities of the Kompepar in developing nature-based tourism objects and local wisdom in Kabupaten Pangandaran. The method used in this study is descriptive with the nature of quantitative data based on data collection techniques through observation and questionnaires distributed to respondents randomly simple. The results showed that the intensity of internal communication in the form of regular meetings among kompepar members was high enough to share information in an effort to increase knowledge, establish relationships, and build awareness for managers of tourism businesses to actively participate in tourism activities in Kabupaten Pangandaran. While the aspect of cohesiveness among kompepar members in Kabupaten Pangandaran can be categorized high in building common ground, increasing insight, dividing tasks, and collaborating to achieve group goals.
\end{abstract}

Key words: internal communication; cohesivitas; competitiveness; competitiveness; division of tasks; cooperation

\section{PENDAHULUAN}

Komunikasi dalam kegiatan pariwisata sangat penting karena dengan komunikasi dapat membangun pengetahuan, perasaan, keinginan, dan keikutsertaan orang untuk mengunjungi objek wisata di suatu daerah. Atau dengan kata lain, komunikasi dapat dijadikan alat untuk mempromosikan destinasi wisata. Kabupaten Pangandaran salah satu daerah wisata yang telah memanfaatkan komunikasi untuk mempromosikan objek wisatanya. Aktivitas komunikasi begitu marak dalam mempromosikan objek wisata, baik komunikasi dengan menggunakan media sosial, media massa, maupun komunikasi langsung tatap muka di antara para pihak yang terlibat di dalamnya.

Salah satu pihak yang terlibat dalam aktivitas komunikasi kepariwisataan di Kabupaten Pangandaran adalah para penggiat wisata yang tergabung ke dalam Kelompok Pegiat Pariwisata (kompepar). Mereka merupakan salah satu pemangku kepentingan yang menjadi garda terdepan dalammenjalankan aktivitasnyamempromosikan destinasi wisata. Mereka juga berasal dari berbagai komponen, seperti pemandu wisata, pengusaha hotel dan restoran, perjalanan wisata, penggiat budaya, dan anggota masyarakat lainnya yang bekerja sama untuk mencapai tujuan bersama. Keberadaan kompepar tersebut sangat penting bagi pemerintah, karena sebagai salah satu unsur masyarakat pariwisata yang memiliki komitmen untuk mencapai tujuan, dan cita-cita membantu pemerintah untuk memajukan program kepariwisataan di wilayah kerjanya. Komitmen kompepar khususnya di Kabupaten Pangandaran bisa terbentuk karena di antara anggotaanggotanya memiliki tujuan dan cita-cita yang sama untuk membangun kepariwisataan di wilayah tersebut. 
Kesamaan tujuan dan cita-cita di antara anggota kompepar tidak muncul begitu saja, melainkan hasil dari suatu interaksi yang intensif. Dalam interaksi tersebut, faktor komunikasi memiliki peran yang sangat fundamental, karena melalui komunikasi di antara mereka terjadi proses saling berbagi informasi untuk membangun kesamaan makna, menetapkan tujuan kelompok, dan mengambil keputusan tentang masalah kepariwisataan.

Komunikasi internal yang terjadi di dalam kompepar menjadi sangat penting, karena dapat mempersatukan para anggotanya yang berasal dari berbagai elemen pegiat pariwisata yang ada di Kabupaten Pangandaran. Dengan komunikasi internal, anggota kompepar satu sama lain saling melakukan pertukaran informasi sesuai dengan kepentingan masing-masing dalam rangka membangun kesepahaman dan kerja sama, dan mempererat hubungan yang harmonis di antara para anggotanya.

Dinamika komunikasi internal kompepar di Kabupaten Pangandaran dapat dilihat dari intensitas dan situasi komunikasinya. Kenggotaan Kompepar yang berasal/wakil dari pegiat wisata yang heterogen tersebut memerlukan intensitas komunikasi yang tinggi dengan situasi komunikasi yang kondusif. Dengan heterogenitas anggota Kompepar tersebut dimungkinkan masingmasing anggota membawa kepentingannya sesuai dengan tupoksi mereka di perusahaan/organisasi/komunitasnya yang menjadi induknya.

Heterogenitas individu-individu yang tergabung dalam Kompepar tersebut membawa nilai-nilai yang telah terbentuk selama dirinya berada di lingkungan organisasi sebelumnya, sehingga dalam dirinya telah terbentuk sistem internal yang berpengaruh terhadap caranya berkomunikasi dengan individu lain yang berasal dari organisasi yang berbeda. Menurut (Mulyana, 2013), yang termasuk ke dalam sistem internal tersebut meliputi frame of reference, field of experience, cognitive structure, thinking patterns, state internal, dan attitude. Durkheim (dalam Ritzer, George, 2009), "heterogenitas dapat menciptakan pembagian kerja, dan pembagian kerja bisa menciptakan solidaritas".

Oleh karena itu, dengan komunikasi internal kepentingan para anggotanya diharapkan dapat terakomodasi, perbedaan pendapat dapat dieliminasi, konflik dapat dihindari, dan tujuan kelompok dapat tercapai, sehingga mereka memiliki "sense of belonging" terhadap kmpepar tersebut. Untuk itu, komunikasi yang cepat dan efektif sangat diperlukan (Dwi \& Putra, 2008). Sementara itu, menurut Tubbs dan Moss (dalam Rakhmat, 2018), komunikasi dikatakan efektif apabila menimbulkan pengertian, kesenangan, pengaruh pada sikap, hubungan yang baik, dan tindakan.

Komunikasi internal sendiri menurut Lawrence D. Brennan (dalam Effendy, 2011) sebagai pertukaran gagasan (secara horizontal dan vertikal) di antara para administrator dan karyawan dalam suatu perusahaan atau organisasi guna terwujudnya tujuan perusahaan. Adapun tujuan dari komunikasi itu sendiri menurut Pace, Peterson, dan Burnett (dalam Effendy, 2011: 32) adalah untuk memastikan komunikan memahami makna dari pesan yang diterima (to secure understanding), terus memelihara dan membina penerimaan tersebut (to establish acceptance), dan memotivasi komunikan untuk melakukan suatu kegiatan (to motive action). Sedangkan menurut Cutlip (dalam Theaker, 2001), tujuan dari komunikasi internal yaitu untuk identifikasi, membangun dan menjaga hubungan timbal balik antara organisasi dan karyawan, dimana kesuksesan sebuah organisasi sangat ditentukan oleh karyawannya.

Berkaitan dengan pengembangan wisata berbasis alam dan budaya di Kabupaten Pangandaran ini, diperlukan kohesivitas kelompok penggerak wisata di daerah (kompepar) tersebut. Sebagaimana hal ini menurut Collins dan Raven (Rakhmat, 2018) menyatakan bahwa kohesivitas kelompok didefinisikan sebagai kekuatan yang mendorong anggota kelompok untuk tetap tinggal dalam kelompok, mencegahnya meninggalkan kelompok. Pada kelompok kohesif para anggotanya terikat kuat dengan kelompoknya, maka mereka menjadi mudah melakukan konformitas. Makin kohesif sebuah kelompok, makin mudah angota-anggotanya untuk tunduk pada norma kelompok (Rakhmat, 2018). Kohesif adalah batas hingga di mana anggota-anggota suatu kelompok bersedia untuk bekerjasama. Kelompok menjadi kohesif tugas-tugas mereka dan anggota-anggotanya merasa dimampukan untuk melakukan tugas-tugas tambahan (West, Richard, 2008). Sebagai batas, kohesif dapat memisahkan peran masing-masing anggotanya, dan ketaatannya pada kelompok yang dapat mengarahkan mereka pada kerja sama kelompok untuk mencapai tujuan bersama.

Kohesivitas kelompok terjadinya juga pada kompepar di Kabupaten Pangandaran. Hal ini bisa dilihat dari aktivitas komunikasi internal dan kerja sama berjalan dengan kondusif. Kompepar menjadi mitra pemerintah dalam pembangunan kepariwisataan di Kabupaten Pangandaran, di mana dalam hal ini masyarakat diberdayakan sedemikan rupa agar mereka paham dan berpartisipasi dalam pembangunan pariwisata tersebut. Pola kemitraan yang terbangun antara pemerintah dengan masyarakat cenderung mengarah kepada pemberdayaan masyarakat lokal (Ami Suwandi Putra, 2013). Salah satu elemen penting untuk menjadi anggota kompepar adalah pegiat wisata, mereka perlu diberdayakan agar mereka memahami potensi wisata dan berpartisipasi dalam pengembangannya di wilayah tersebut.

Kompepar merupakan tempat para anggotanya berinteraksi, komunikasi menjadi landasan utama untuk 
bertukar informasi untuk membangun kesepahaman dan kerja sama untuk mencapai tujuan bersama, yaitu membangun sektor pariwisata berbasis kearifan lokal. Untuk itu, penulisan ini bertujuan untuk menjelaskan aktivitas komunikasi internal dalam Kompepar, dan kohesivitas kelompok yang terbangun dalam kmpepar di Kabupaten Pangandaran.

\section{METODE}

Metode yang digunakan dalam penelitian ini adalah deskrtiptif, yang menurut (Rakhmat, 2008) studi penelitian deskriptif adalah sebuah metode yang bertujuan melukiskan secara sistematis fakta atau karakteristik populasi dibidang tertentu secara fakta dan cermat. Fakta atau karakteristik yang dilukiskan dalam penelitian ini terdiri dari variabel komunikasi internal, yang meliputi intensitas komunikasi internal, aktivitas komunikasi langsung dan tidak langsung, intensitas perbedaan pendapat, dan intensitas pertukaran informasi yang dilakukan oleh anggota kompepar. Variabel lainnya yang diambil dalam penelitian ini adalah kohesivitas kompepar yang meliputi kesamaan pandangan, tempat/wadah belajar, peningkatan wawasan, pembagian tugas, dan kerja sama.

\section{HASIL DAN PEMBAHASAN}

Komunikasi dalam pengembangan pariwisata secara intensif dilakukan oleh anggota Kompepar di Kabupaten Pangandaran, dimana komunikasi internal menjadi salah satu aktivitas yang rutin terjadi. Komunikas internal yang terjadi pada kelompok tersebut dapat dilihat dari intesitas, proses, dan situasinya, yang pada akhirnya berkaitan dengan keeratan kelompok (kohesivitas) dalam Kompepar tersebut. Hasil penelitian tentang komunikasi internal dan kohesivitas yang terjadi dalam Kompepar tersebut dapat disajikan dalam tabel sebagai berikut.

Tabel 1. Distribusi Frekuensi Responden berdasarkan Intensitas Komunikasi Internal

\begin{tabular}{ccc}
\hline $\begin{array}{c}\text { Intensitas Komunikasi } \\
\text { Internal }\end{array}$ & Frekuensi & Persentase \\
\hline Tidak Pernah & - & - \\
Jarang Sekali & - & - \\
Kadang-kadang & 7 & $23,33 \%$ \\
Sering & 18 & $60,00 \%$ \\
Sangat Sering & 5 & $16.67 \%$ \\
\hline Total & $\mathbf{3 0}$ & $\mathbf{1 0 0 \%}$ \\
\hline
\end{tabular}

Sumber: Hasil Penelitian, 2017

Teknik pengumpulan data dilakukan melalui observasi dan kuesioner yang dibagikan kepada sampel sebesar 30 orang dengan menggunakan acak sederhana. Teknik analisis data menggunakan statistik deskripfif, yaitu dengan menganalisis data hasil penelitian yang telah tersaji di dalam tabel 1 .

Tabel 1. menunjukkan bahwa, seluruh responden melakukan aktivitas komunikasi internal dalam Kompepar. Mayoritas responden menyatakan sering melakukan komunikasi internal dalam Kompepar, yaitu $60,00 \%$, sedangkan yang sangat sering $16,67 \%$, dan yang kadang-kadang 23,33\%.

Data di atas mengindikasikan bahwa Kompepar merupakan suatu kelompok yang menjadikan komunikasi sebagai dasar untuk melaksanakan aktivitas kepariwisataan di Kabupaten Pangandaran. Keanggotaan Kompepar sangat heterogen karena mereka berasal/wakil dari organisasi yang terlibat dalam dunia kepariwisataan, sehingga dengan keheterogenannya, para anggota membutuhkan komunikasi untuk mengimplementasikan kepentingannya masing-masing, dan menghindari krisis komunikasi dalam kelompok tersebut. Oleh karena itu, ketika krisis komunikasi yang menimbulkan kurang harmonisnya hubungan yang melanda mereka, keputusan harus segera diambil, dilaksanakan dan dibicarakan kepada anggota kelompok, sehingga hubungan baik di antara anggota kelompok tersebut bisa dipertahankan, dan kebijakan tentang masalah kepariwisataan dapat dikomunikasikan (Dwi \& Putra, 2008). Oleh karena itu, intensitas komunikasi internal yang terjadi dalam kompepar di Kabupaten Pangandaran tergolong tinggi.

Komunikasi internal di dalam Kompepar di atas berkaitan dengan fungsi komunikasi itu sendiri, yaitu fungsi sosial, dan pengambilan keputusan. Fungsi sosial bisa dilihat pada saat para anggotanya yang berasal berbagai elemen tersebut melakukan tukar-menukar informasi untuk meningkatkan pengetahuan, menjalin relasi dan membangun kesadaran pengelola usaha pariwisata untuk berpartisipasi aktif dalam kegiatan kepariwisataaan di Kabupaten Pangandaran. Oleh karena itu, membangun komunikasi dapat mengakibatkan terpenuhinya kebutuhan emosional, intelektual, dan hubungan yang harmonis dengan orang lain dalam suatu kelompok (Mudjiono, 2012).

Fungsi pengambilan keputusan dapat dapat dilakukan oleh mereka yang tergabung dalam Kompepar dengan memutuskan untuk melakukan tindakan-tindakan tertentu di bidang pariwisata yang disesuaikan dengan kepentingan perusahaan/organisasi yang diwakilinya. Dengan demikian, komunikasi memiliki hubungan yang positif dan signifikan dengan pengambilan keputusan (Lestari, 2015). Berjalannya fungsi komunikasi secara sosial, dan pengambilan keputusan mengembangkan pariwisata yang terjadi pada kompepar di Kabupaten Pangandaran menunjukkan bahwa komunikasi tersebut berlangsung efektif. Hal ini disebabkan bahwa komunikasi internal memberikan kontribusi informasi yang dibutuhkan, 
sehingga dapat menimbulkan kepuasan kerja (Neonisa, 2011)

Tabel 2. Distribusi Frekuensi Responden berdasarkan Intensitas Komunikasi Langsung

\begin{tabular}{ccc}
\hline $\begin{array}{c}\text { Intensitas Komunikasi } \\
\text { Langsung }\end{array}$ & Frekuensi & Persentase \\
\hline Tidak Pernah & - & - \\
Jarang Sekali & - & - \\
Kadang-kadang & 6 & $20,00 \%$ \\
Sering & 21 & $70,00 \%$ \\
Sangat Sering & 3 & $10.00 \%$ \\
\hline Total & $\mathbf{3 0}$ & $\mathbf{1 0 0 \%}$ \\
\hline
\end{tabular}

Sumber: Hasil Penelitian, 2017

Tabel 2. menunjukkan bahwa seluruh responden melakukan aktivitas komunikasi langsung. Mayoritas dari mereka menyatakan sering melakukan komunikasi langsung dalam Kompepar, yaitu 70,00\%, sangat sering 10,00\%, dan kadang-kadang 20,00\%.

Komunikasi langsungyang terjadi pada Kompepardi Kabupaten Pangandaran, umumnya terjadi ketika mereka berada dalam berbagai pertemuan kelompok, atau ketika mereka berada di luar situasi kelompok, seperti ketika sedang menjalankan tugas pokok dan fungsinya sesuai perusahaan/organisasi yang diwakilinya. Komunikasi pada situasi kelompok ini sangat memungkinkan pesertanya melakukan aktivitas komunikasi antarpersona.

Komunikasi langsung yang terjadi pada Kompepar lebih pada upaya yang dilakukan oleh anggota kelompok itu dalam mengirim dan menerima informasi langsung di antara kedua belah pihak, baik person to person, maupun person to group, tanpa perantara orang lain. Mereka yang berkomunikasi berharap melakukan tindakan sama sesuai dengan tujuan, harapan atau isi pesan yang disampaikan (Ahmad, 2014). Komunikasi langsung ini memungkinkan kedua belah pihak dapat mencapai kesepakatan tentang masalah yang berkaitan dengan kepariwisataan di Kabupaten Pangandaran.

Para anggota Kompepar di Kabupaten Pangandaran melakukan komunikasi langsung tanpa perantara menunjukkan hubungan interpersonal di antara mereka telah terbangun dengan baik. Hal ini bisa terjadi, karena komunikasi langsung dilakukan secara terbuka, bisa langsung ditanggapi, sehingga mempermudah terbangunnya kesepahaman. Sikap terbuka ini memiliki pengaruh yang sangat besar dalam membangun efektivitas komunikasi interpersonal (Rakhmat, 2018). Para anggota yang tergabung dalam Kompepar tersebut satu sama lain saling membutuhkan informasi faktual untuk memperjelas segala sesuaty yang berkaitan dengan persoalan kepariwisataan.

Sikap terbuka untuk menerima itulah mereka dapat memperoleh informasi yang dibutuhkan. Hal ini menurut
Bormann (dalam Rakhmat, 2018), anggota kelompok akan bertanya tentang informasi yang mereka butuhkan, karena takut kelihatan bodoh, dan kehilangan muka. Oleh karena itu, komunikasi langsung ini menjadi penting bagi mereka untuk dimanfaatkan untuk bertukar informasi yang berkaitan dengan dunia kepariwisataan di Kabupaten Pangandaran.

Namun demikian, ada juga anggota Kompepar yang kadang-kadang melakukan komunikasi tidak langsung dengan memanfaatkan perantaraan orang lain untuk dimintai bantuannya ketika bertanya atau menyampaikan pesan kepada pihak yang dituju.

Individu-individu yang tergabung dalam Kompepar berasal dari atau perwakilan dari organisasi/perusahaan yang bergerak dalam kegiatan kepariwisataan, seperti hotel, restoran, perjalanan wisata, pemandu wisata, dan sebagainya yang tentu saja kendala psikologis bisa menjadi masalah bagi sebagian dari mereka, seperti status di tempat kerja asalnya yang tidak semuanya berada pada tataran manajemen, keterbatasan pengetahuan, dan kualitas interaksi yang dialami oleh sebagian dari mereka, terutama pada saat berkomunikasi dengan individu lain dalam kelompok tersebut. Interaksi ini menjadi hambatan yang merintangi individu pada saat melakukan komunikasi, sehingga dapat berakibat buruk dan merugikan bagi yang bersangkutan (Harivarman, 2018). Hambatan komunikasi ini berpengaruh pada efektivitas komunikasi yang dilakukan individu tersebut.

Individu yang melakukan komunikasi tidak langsung, hanya sebagian kecil saja, sehingga interaksi yang terjadi pada Kompepar tidak menjadi persoalan yang krusial, dan kulaitas hubungan di antara individu di Kompepar Kabupaten Pangandaran masih terjaga dengan baik. Komunikasi yang efektif dapat membangun hubungan baik, menyelesaikan perbedan pendapat, dan dapat mengatasi konflik (Hijrah, 2017). Oleh karena itu, interaksi dalam kelimpok ini begitu terjaga, karena para anggotanya menyadari bahwa interaksi dapat menambah wawasan, dan membangun kerja sama dalam bidang kepariwisataan.

Tabel 3. Distribusi Frekuensi Responden berdasarkan Intensitas Perbedaan Pendapat

\begin{tabular}{ccc}
\hline $\begin{array}{c}\text { Intensitas Perbedaan } \\
\text { Pendapat }\end{array}$ & Frekuensi & Persentase \\
\hline Tidak Pernah & 16 & $53,33 \%$ \\
Jarang Sekali & 11 & $36,67 \%$ \\
Kadang-kadang & 3 & $10,00 \%$ \\
Sering & - & - \\
Sangat Sering & - & - \\
\hline Total & $\mathbf{3 0}$ & $\mathbf{1 0 0} \%$ \\
\hline
\end{tabular}

Sumber: Hasil Penelitian, 2017 
Tabel 3. Menunjukkan bahwa responden yang tergabung dalam Kompepar di Kabupaten Pangandaran mayoritas, yaitu 53,33\% tidak pernah berbeda pendapat tentang persoalan kepariwisataan dengan orang lain dalam kelompok tersebut. Responden yang jarang sekali berbeda pendapat berjumlah $36,67 \%$, dan yang kadang-kadang berbeda pendapat ada $10,00 \%$.

Terjadinya perbedaan pendapat dalam suatu kelompok merupakan hal yang wajar, karena setiap individu yang tergabung dalam kelompok tersebut berasal dari latar belakang yang berbeda, sehingga kepentingnnya pun bisa berbeda pula. Demikian halnya juga yang terjadi dalam Kompepar di Kabupaten pangandaran. Walaupun intensitas perbedaan pendapat tersebut kecil, tetap menunjukkan adanya demokrasi yang mengarah kepada kesepakatan bersama tentang persoalan pariwisata. Perbedaan pendapat di antara individu menjadi landasan dalam musyawarah untuk mengambil keputusan (Wijayanta, 2007).

Minimnya perbedaan pendapat di antara individuindividu yang tergabung dalam Kompepar di Kabupaten Pangandaran ini dilandasi oleh kepercayaan di antara mereka. Kepercayaan tersebut merupakan faktor sosiopsikologis yang berkaitan dengan pemahaman mereka tentang eksistensi kompepar sebagai suatu organisasi yang dapat memfasilitasi kepentingan para anggotanya yang berasal dari organsasi/kelompok yang berbeda dalam memperlancar usaha pariwisata di Kabupaten Pangandaran. Kepercayaan ini memberikan gambaran kepada inividu-individu dalam mempersesi realitas, mengambil keputusan, dan menentukan sikapnya (Rakhmat, 2018). Oleh karena itu, gambaran realitas Kompepar yang terbentuk dalam diri individu-individu tersebut menjadi bahan bagi dirinya untuk mengambil keputusan dan membangun sikapnya terhadap kelompok tersebut, termasuk di antaranya mengambil keputusan dn sikap untuk tidak berbeda pendapat.

Biasanya perbedaan pendapat pada kompepar lebih kepada hal-hal yang sifatnya teknis bukan pada masalah kebijakan kelompok. Pembuatan kebijakan di bidang kepariwisataan disusun oleh Instansi terkait, sedangkan pelaksanaan kebijakan dilakukan oleh Kompepar. Dalam pelaksanaan kebijakan tersebut masih ada perbedan pendapat, walaupun instensitasnya sangat kecil. Hal ini bisa terjadi, karena Kompepar di Kabupaten Pangandaran ini sangat heterogen, sehingga potensi perbedaan pendapat tidak bisa dihindari. Setiap individu yang tergabung dalam kelompok tersebut mewakili kepentingan masing-masing, sehingga kepentingan ini membawa ke dalam situasi perbedaan pendapat/interpretasi, tujuan, dan sebagainya. Dalam konteks kehidupan sosial, perbedaan interpretasi, preferensi, dan tujuan dari tiap individu yang ada dalam kelompok mencerminkan kehidupan tentang demokrasi (Sukri, 2016). Oleh karena itu, Kompepar di Kabupaten
Pangandaran sangat menghargai perbedaan pendapat, sehingga konflik bisa dihindari seminimal mungkin.

Tidak adanya perbedaan pendapat di antara anggota Kompepar disebabkan mereka sering bertukar pikiran mengenai pengembangan pariwisata, dan dalam di antara mereka saling mengakomodir kepentingan masingmasing.

Pertukaran informasi merupakan aktivitas yang rutin terjadi dalam sebuah kelompok/organisasi dengan tujuan untuk mencapai kesepahaman/kesamaan makna dari pesan yang dipertukarkan. Demikian halnya yang terjadi dalam Kompepar, di Kabupaten Pangandaran ini semua individu pernah bahkan sering bertukar informasi dengan individu lainnya. Semakin tinggi intensitas ber-interaksi di antara satu individu dengan individu lain, maka informasi yang dipertukarkan semakin banyak pula (Hertanto \& Safitri, 2016). Pertukaran informasi tersebut pada akhirnya akan menambah pengetahuan, dan meningkatkan kompetensi mereka yang tergabung dalam Kompepar tentang persoalan kepariwisataan di Kabupaten Pangandaran.

Aktivitas komunikasi berupa pertukaran informasi dalam Kompepar di Kabupaten Pangandaran tersebut menunjukan bahwa komunikasi dalam kelompok tersebut itu bersifat dinamis. Semua orang terlibat di dalam pertukaran informasi, sehingga mereka merupakan sumber informasi untuk saling mempengaruhi, sehingga berimplikasi terhadap perubahan pengetahuan, penilaian, dan perilakunya. Kecenderungan individu melakukan komunikasi didasarkan pada kepercayaan, kedekatan, kebutuhan, dan pengalaman sumber informasi (Hertanto \& Safitri, 2016). Oleh karena itu, Dinamika komunikasi yang terjadi dalam Kompepar menjadikan kelompok tersebut solid.

Proses pertukaran informasi yang dilakukan oleh individu-individu yang tergabung ke dalam Kompepar di Kabupaten Pangandaran menunjukkan bahwa mereka itu memiliki sikap terbuka terhadap informasi yang disampaikan orang lain sesuai dengan kebutuhannya. Dengan memahami dan mendengarkan orang lain, keterbukaan dan kepercayaan akan terbentuk, sehingga kerjasama yang sinergi dengan orang lain dapat terbangun (Handayani, 2011).

Tabel 4. Distribusi Frekuensi Responden berdasarkan Kesamaan Pandangan

\begin{tabular}{ccc}
\hline Kesamaan Pandangan & Frekuensi & Persentase \\
\hline Sangat Setuju & 13 & $43,33 \%$ \\
Setuju & 16 & $53,33 \%$ \\
Tidak Tahu & 1 & $3,34 \%$ \\
Tidak Setuju & - & - \\
Sangat Tidak Setuju & - & - \\
\hline Total & $\mathbf{3 0}$ & $\mathbf{1 0 0 \%}$ \\
\hline
\end{tabular}

Sumber: Hasil Penelitian, 2017 
Tabel 4 menunjukkan semua responden menyatakan bahwa dirinya merasakan dalam Kompepar di Kabupaten Pangandaran terdapat kesamaan pandangan. Mayoritas dari mereka menyatkan setuju ada ksamaan pandangan, yaitu $53.33 \%$, yang menyatakan sangat setuju adanya kesamaan pandangan berjumlah 43,33\%, dan yang menyatakan tidak tahu ada 3,34\%.

Sebagai mahluk sosial, individu-individu selalu menjalin hubungan di antara mereka yang didasarkan ke pada kepentingan yang sama, di mana kesamaan tersebut pada akhirnya dapat mempererat dan meningkatkan kualitas dari hubungan tersebut. Demikian halnya yang terjadi pada individu-individu yang tergabung dalam Kompepar di Kabupaten Pangandaran, di antara mereka memiliki kesamaan pandangan terhadap tujuan kelompoknya, yaitu membangun sektor wisata berbasis kearifan lokal dengan mendayagunakan masyarakat lokal. Kesamaan pandangan ini bisa terjadi, karena masing-masing individu mempunyai pendapat yang sama (Badri, 2018). Kesamaan pandangan memberi kenyamanan dalam berinteraksi kepada para anggota Kompepar di Kabupaten Pangandaran, karena mereka diikat oleh kepentingan yang sama dalam Kompepar yaitu mewujudkan pembangunan kepariwisataan, walaupun mereka berasal organisasi/ kelompok yang berbeda yang tentunya mempunyai kepentingan masing-masin. Oleh karena itu, menurut Janis (dalam West, Richard, 2008) kelompok dapat memberikan tekanan yang besar kepada anggotanya untuk menaati standar kelompok. Adapun standar Kompepar di Kabupaten Pangandaran antara lain adalah meningkatkan partisipasi pelaku usaha pariwisata dan masyarakat dalam menata pelayanan dan kebutuhan wisatawan dalam hal obyek dan daya tarik wisata.

Kesamaan pandangan para anggota Kompepar di Pangandaran tentang tujuan membangun sektor wisata berbasis kearifan lokal didasarkan pada realitas bahwa di Kabupaten Pangandaran potensi wisata budaya sangat banyak, baik berupa kesenian,maupun praktikpraktik ritual warisan nenek moyang yang sampai sat ini masih dilaksanakan, sehingga realitas tersebut menjadi bekal pengetahuan bagi para anggota Kompepar untuk membangun pandangan yang sama dan saling berempati dalam mewujudkan tujuan kelompok tersebut. Oleh karena itu, dalam membangun kesepahaman bersama, maka diperlukan empati dengan saling menepatkan kerangka pikir di antara individu-individu yang terlibat di dalamnya (Amal Taufik, 2013). Menempatkan kerangka pikir ini dikarenakan, mereka berasal dari organisasi/kelompok yang berebeda. Oleh karena itu, di antara individuindividu tersebut berusaha mensinergikan sistem internal yang ada dalam dirinya, seperti frame of reference, field of experience, dan sebagainya agar kesamaan pandangan tetap terjaga.
Tabel 5. Distribusi Frekuensi Responden berdasarkan Pernyataan Kompepar sebagai Wadah

\begin{tabular}{ccc}
\hline Kompepar Sebagai Wadah & Frekuensi & Persentase \\
\hline Sangat Setuju & 12 & $40 \%$ \\
Setuju & 17 & $56,67 \%$ \\
Tidak Tahu & 1 & $3,33 \%$ \\
Tidak Setuju & - & - \\
Sangat Tidak Setuju & - & - \\
\hline Total & $\mathbf{3 0}$ & $\mathbf{1 0 0 \%}$ \\
\hline & Sumber: Hasil Penelitian, 2017
\end{tabular}

Tabel 5 menunjukkan semua responden menyatakan bahwa Kompepar merupakan wadah untuk mencapai tujuan kelompok, di mana mayoritas dari mereka yang menyatakan setuju ada 56,57\%, responden yang menyatakan sangat setuju ada $40 \%$, dan responden yang menyatakan tidak tahu ada 3,33\%.

Pada kenyataannya Kompepar di Pangandaran merupakan suatu wadah untuk mencapai tujuan kelompok, yaitu membangun sektor wisata berbasis kearifan lokal dengan mendayagunakan masyarakat lokal. Sebagai sebuah wadah, Kompepar menampung berbagai individu yang berasal dari perusahaan/organisasi, komunitas, anggota masyarakat lokal, dan sebagainya, yang memiliki kepedulian terhadap kepariwisataan di Pangandaran.

Untuk mencapai tujuan tersebut, Kompepar harus memanfaatkan segala sumber daya potensial untuk mencapai tujuan tersebut secara efektif dan efesien. Oleh karena itu, manajemen kelompok harus memberi ruang pada pengembangan sumberdaya manusia, mensinergikan antara pariwisata dan sosial budaya masyarakat, mengoptimalkan pemanfaatan teknologi, dan memperjelas pengorganisasian komunitas masyarakat (Ami Suwandi Putra, 2013). Hal yang sama menyatakan bahwa, kelompok menjadi wadah untuk memanfaatkan berbagai sumber daya secara bersama-sama, dan wadah untuk mengembangkan potensi dan spesialisasi yang dimilik individu (Saefrudin, 2017). Dengan demikian, Kompepar menjadi sebuah wadah untuk membangun produktivitas di bidang kepariwisataan yang dapat membantu pemerintah Kabupaten Pangandaran meningkatkan perekonomiannya dari sektor wisata.

Pemanfaatan dan pemberdayaan sumberdaya kelompok, khusunya individu-indivu yang berasal dari berbagai perwakilan tersebut disesuaikan dengan kompetensi dan tupoksi dari tempatnya dia berasal, sehingga mereka yang terlibat dalam aktivitas Kompepar merupakan mitra kerja dalam mencapai tujuan kelompok. Namun demikian, untuk membangun kemitraan yang baik, koordinasi dan komunikasi harus berjalan dengan baik pula (Rahajeng and Manaf, 2015). Oleh karena itu, sebagai sebuah wadah, Kompepar di Kabupaten Pangandaran berusaha 
mengakomodir berbagai kepentingan para anggotanya, menjalin komunikasi yang baik, dan melakukan koordinasi kerja untuk mencapai tujuan bersama.

Sebagai sebuah wadah, Kompepar membantu para anggotanya untuk meningkatkan wawasan. Selain itu Kompepar merupakan sebuah kelompok formal, dimana para anggotanya memiliki harapan, dan pengalaman yang berkaitan dengan masalah intelektual. Pengalaman intelektual ini berkaitan dengan masalah keterbatasan pengetahuan dirinya, sehingga memerlukan bantuan dan bimbingan dari orang lain yang ada dalam kelompok tersebut. Proses bantuan dan bimbingan tersebut dapat membangun dan bahkan meningkatkan wawasan tentang masalah kepariwisataan. Kelompok memiliki peran dalam meningkatkan pengetahuan dan apresiasi tentang produk wisatan sebagai sebuah pengalaman (Nafila, 2013). Ini semua merupakan fasilitas kelompok yang dapat dimanfaatkan oleh individu-individu yang terlibat di dalamnya.

Kompepar juga merupakan sebuah wadah di mana setiap individu dapat betukar informasi untuk membangun kesamaan makna tentang pariwisata. Berbagai informasi yang berkaitan dengan pengembangan pariwisata di Kabupaten Pangandaran dapat dengan mudah dikomunikasikan, baik secara informal maupun formal. Komunikasi informal dilakukan untuk membuka akses, melakukan pendekatan, dan memberi penjelasan. Komunikasi formal dilakukan untuk mempertegas tujuan kegiatan (Arofah, 2013). Komunikasi informal dan formal ini merupakan sarana yang dapat membantu mereka untuk membangun dan meningkatkan wawasan tentang kepariwisataan di Kabupaten Pangandaran. Kompepar merupakan ingroup sekunder yang individu-individu yang terlibat di dalamnya berinteraksi dan berkomunikasi untuk berbagi pengalaman dan meningkatkan wawasan tentang dunia kepariwisataan. Peningkatan wawasan tersebut menjadi modal bagi mereka untuk meningkatkan/ memperlancar kualitas kerjanya di bidang pariwisata. Peningkatan kualitas kerja ini menurut Allport (dalam Rakhmat, 2018) disebut sebagai fasilitas sosial, di mana pekerjaan menjadi mudah karena ada pengaruh dari kelompok.

Tabel 6. Distribusi Frekuensi Responden berdasarkan Pembagian Tugas

\begin{tabular}{ccc}
\hline Pembagian Tugas & Frekuensi & Persentase \\
\hline Sangat Setuju & 8 & $26,67 \%$ \\
Setuju & 20 & $66,67 \%$ \\
Tidak Tahu & 2 & $6,66 \%$ \\
Tidak Setuju & - & - \\
Sangat Tidak Setuju & - & - \\
\hline Total & $\mathbf{3 0}$ & $\mathbf{1 0 0 \%}$
\end{tabular}

Tabel 6 menunjukkan semua responden menyatakan bahwa dalam Kompepar di Kabupaten Pangandaran terdapat pembagian tugas. Responden yang menyatakan setuju terhadap pernyataan tersebut berjumlah $66,67 \%$, responden yang menyatakan sangat setuju terhadap pernyataan tersebut ada $26,67 \%$, sedangkan responden yang menyatakan tidak tahu ada $6,66 \%$.

Kompepar merupakan kelompok yang terdiri dari sejumlah orang berperan dalam mewujudkan tujuan bersama, yaitu membangun sektor wisata berbasis kearifan lokal dengan mendayagunakan masyarakat lokal. Dalam melaksanakan perannya tersebut, mereka bekerja sesuai dengan tugas pokok dan fungsi (tupoksi) masing-masing yang disesuaikan dengan bidang kerja organisasi yg diwakilinya. Tupoksi tersebut merupakan implementasi dari pembagian tugas kelompok. Pembagian kerja ternyata memiliki pengaruh yang signifikan terhadap efisiensi kerja anggota (Widia Prastyanti, 2017). Hal ini bisa terjadi pada anggota Kompepar, karena setiap individu bisa fokus bekerja sesuai dengan bidangnya msing-masing dan tidak terjadi tumpang tindih.

Pembagian tugas dalam Kompepar ini tentunya memerlukan kompetensi berkomunikasi, kemampuan dalam menyimak, menyusun perencanaan, mengambil keputusan, dan cara menyelesaikan masalah kepariwisataan sesuai dengan tupoksi perusahaan/organisasi asal mereka. Semua kompetensi tersebut dapat berimplikasi terhadap efektivitas kerja anggota Kompepar. Dengan demikian, pembagian tugas yang baik berhubungan dengan efekti-vitas kerja yang baik pula (Murti, 2015). Oleh karena itu, pengakuan terhadap kemampuan anggota Kompepar dalam melaksanakan tugas menjadi hal yang penting dalam membangun kelompok yang kohesif untuk mengembangkan pariwisata di Kabupaten Pangandaran. Kelompok menjadi kohesif, karena anggota-anggotanya merasa dimampukan untuk melakukan tugas-tugas, sehingga dirinya menjadi antusias dalam melaksanakan tugastugasnya tersebut (West, Richard, 2008).

Pembagian tugas dalam Kompepar membantu anggotanya untuk mengembangan diri, dan melatih fokus dalam melaksanakan tugasnya. Dengan pembagian kerja, setiap individu yang berasal dari berbagai organisasi/kelompok pegiat wisata (heterogen), tergabung dalam Kompepar di Kabupaten Pangandaran menjadi terintegrasi, sehingga dapat bertambah ketrampilannya dalam melaksanakan tugasnya tersebut. Pembagian kerja ini menurut Durkheim (dalam Ritzer, George, 2009) mampu menciptakan sebuah integrasi dalam heterogenitas yang didasarkan pada solidaritas.

Tabel 6. Menunjukkan pernyataan bahwa dalam Kompepar di Kabupaten Pangandaran terdapat kerja sama. Responden yang menyatakan setuju terhadap pernyataan tersebut berjumlah 53,33\%, responden yang 
menyatakan sangat setuju terhadap pernyataan tersebut ada $43,33 \%$, sedangkan responden yang menyatakan tidak tahu ada $3,34 \%$.

Kerja sama merupakan tindakan yang dilakukan individu-individu yang tergabung dalam Kompepar. Melalui kerja sama ini mereka berusaha untuk meningkatkan produktivitas dengan melaksanakan tugas yang sesuai dengan bidangnya dalam rangka mencapai tujuan membangun dunia kepariwisataan di Kabupaten Pangandaran. Kesediaan anggota-anggota kelompok untuk bekerjasama menunjukkan kelompok tersebut kohesif (West, Richard, 2008). Kerja sama yang dilakukan di antara anggota Kompepar adalah untuk mensinergikan pelayanan wisata, seperti anggota Kompepar yang berasal dari perusahaan perjalanan wisata bekerja sama dengan anggota yang berasal dari perusahaan hotel dan restoran, bekerja sama pula dengan pemandu wisata, dan sebagainya, sehingga pengunjung dapat merasa puas atas pelayanan yang diberikan.

Kerja sama di antara anggota Kompepar tersebut bisa berjalan dengan baik, karena di antara mereka memiliki perasaan dihargai, diterima, dan selanjutnya saling membantu untuk memajukan dunia pariwisata di Kabupaten Pangandaran. Perasaan diterima di dalam komunitas tersebut dapat membangun kohesivitas kelompok yang kuat (Adriana et al., 2016). Kerja sama yang terbangun dalam Kompepar ini selanjutnya dapat membantu pemerintah dalam menciptakan iklim usaha wisata yang sehat.

Terbangunnya kerja sama dalam Kompepar di Kabupaten Pangandaran dalam mencapai tujuan membangun pariwisata meunjukkan bahwa dalam kelompok tersebut telah terbangun komunikasi yang efektif. Komunikasi menjadi unsur yang sangat penting dalam kelompok untuk membangun relasi antara anggotanya untuk membangun kerjasama dalam rangka mencapai tujuan (Setiawati, Ammy Novita, 2018). Dengan demikian, kerja sama yang disertai dengan tanggung jawab individuindividu dalam Kompepar ini dapat menghasilkan produktivitas, sehingga kerja sama kelompok menjadi efektif.

\section{SIMPULAN}

Kompepar di Kabupaten Pangandaran merupakan kelompok yang anggota-anggotanya berasal dari berbagai oganisasi/kelompok pegiat wisata yang terikat oleh tujuan yang sama, yaitu membangun sektor wisata berbasis kearifan lokal dengan mendayagunakan masyarakat lokal. Untuk mencapai tujuan tersebut, mereka aktif berkomunikasi secara internal, baik langsung maupun tidak langsung untuk mencapai kesepakatan bersama dengan meminimalisir perbedaan pendapat tentang persoalan pariwisata.
Pertukaran informasi yang dilakukan anggota kompepar di Kabupaten Pangandaran tersebut menunjukan dinamika komunikasi, semua orang terlibat di dalam pertukaran informasi, sehingga mereka merupakan sumber informasi untuk saling mempengaruhi, sehingga berimplikasi terhadap pengetahuan, penilaian, dan perilakunya. Terjadinya dinamika komunikasi internal dalam kelompok ini dilandasi oleh kepercayaan, kedekatan, kebutuhan, dan pengalaman sebagaisumber informasi. Oleh karena itu, dinamika komunikasi yang terjadi dalam Kompepar menjadikan kelompok tersebut kohesif.

Kompepar di Kabupaten Pangandaran merupakan kelompok yang kohesif, karena merupakan suatu wadah yang para anggotanya memiliki kesamaan pandangan, dapat meningkat wawasannya, sehingga mampu pariwisata yang didasarkan pada pembagian tugas dan kerja sama di antara mereka. Pembagian tugas ini mampu menciptakan sebuah integrasi dalam heterogenitas yang didasarkan pada solidaritas di antara mereka yang berasal dari berbagai organisasi/kelompok pegiat wisata yang bekerja sama untuk meningkatkan produktivitas kelompok.

\section{UCAPAN TERIMA KASIH}

Ucapan terima kasih kami sampaikan ke Pimpinan Rektorat beserta Jajarannya atas telah terselesaikannya penelitian skema Riset Kompetensi Dosen Unggulan dengan pembiayaan Hibah Internal Universitas Padjadjaran 2017-2018.

\section{DAFTAR PUSTAKA}

Adriana, G., Pandjaitan, N. K., Dharmawan, H., Sains, D., Masyarakat, P., Manusia, F. E., \& Bogor, I. P. (2016). Kohesivitas Komunitas Nelayan dalam menghadapi Perubahan Ikllim di Pesisir Jawa Barat (Studi Kasus: di Pedesaan Jawa Barat). (Adger 2006).

Ahmad, O.N. (2014). Komunikasi Sebagai Proses Interaksi. AT-TABSYIR, Jurnal Komunikasi Penyiaran Islam, 2, (2), 17-34.

Amal, T. (2013). Perilaku Ritual Warok Ponorogo Dalam Perspektif Teori. Jurnal Sosiologi Islam, 3, (2), 113-121.

Ami, S.P. (2013). Pola Kemitraan Pariwisata Dalam Manajemen Atraksi Desa Wisata Pampang Kota Samarinda. Jurnal Nasional Pariwisata, 5, (3), 189-200.

Arofah, K. (2013). komunikasi Kelompok Dan eksternalisasi Pengetahuan Tacit Dalam 
Pengambilan Keputusan Organisasi. Jurnal Ilmu Komunikasi, 11, (1), 30-34.

Badri, M.H. (2018). Pemberdayaan Komunikasi Pemuka Pendapat Dalam Penanganan Bencana Gempa Bumi Di Yogyakarta.

Dwi, K., \& Putra, C. (2008). Strategi Public Relations Pariwisata Bali. Jurnal Ilmu Komunikasi, 5, (1), 41-66.

Effendy, O.U. (2011). Ilmu Komunikasi. Teori dan Praktek. Bandung: Remaja Rosda Karya.

George, R.. (2009). Teori Sosiologi (Kedua). Yogyakarta.

Handayani, T. (2011). Membangun Komunikasi Efekti Untuk Meningkatkan Kualitas Dalam Proses Belajar Mengajar. Ta'Dib, XVI, (02), 274-302.

Harivarman, D. (2018). Hambatan Komunikasi Internal di Organisasi Pemerintahan. Jurnal ASPIKOM, 3, (3), 508. https://doi.org/10.24329/aspikom. v3i3.171

Hertanto, D. \& Safitri, R. (2016). Analisis Struktur Jaringan Komunikasi dan Peran Aktor Dalam Penerapan Teknologi Budidaya Kentang (Petani Kentang Desa Ngantru Kecamatan Ngantang Kabupaten Malang) Structure Analysis of Communication Network and The Role Players Technology Application in. Jurnal Habitat, 27, (2), 55-65. https://doi.org/10.21776/ub.habitat.2016.027.2.7

Hijrah. (2017). Hambatan Komunikasi Interpersonal Kaum Lesbian Virginity Dalam Pergaulan SehariHari Di Kota Palu Hijrah. Jurnal Online Kineik, 4, (2), 45-56.

Lestari, S.P. (2015). Keputusan Memilih Jasa Layanan Kesehatan (Studi Kasus Pada Rumah Sakit Islam Lumajang). JURNAL INTERAKSI, 4, (2), 139147.

Mudjiono, Y. (2012). Komunikasi sosial. Jurnal Ilmu Komunikasi, 2, (1), 100-110.

Mulyana, D. (2013). Ilmu Komunikasi Suatu Pengantar. Bandung: PT. Remaja Rosdakarya.
Murti, E. (2015). Pengaruh pembagian kerja terhadap efektifitas organisasi publik di desa karangrejo kecamatan kendal kabupaten ngawi. Jurnal Sosial, 16, (1), 76-91.

Nafila, O. (2013). Peran Komunitas Kreatif dalam Pengembangan Pariwisata Budaya di Situs Megalitikum Gunung Padang. Perencanaan Wilayah Dan Kota, 24, (1), 80. https://doi. org/10.5423/PPJ.2009.25.4.333

Neonisa, D. (2011). Pengarh Komunikasi Internal Terhadap Kepuiasan Kerja Dalam Sebuah Organisasi: Studi Kasus PT XYZ. HUMANIORA, 2, (1), 779-789.

Rakhmat, J. (2008). Metode Penelitian Komunikasi. Bandung: Remaja Risdakarya.

Rakhmat, J. (2018). Psikologi Komunikasi (Revisi). Bandung: Simbiosa Rekatama Media.

Saefrudin. (2017). Pengorganisasian Dalam Manajemen. Jurnal Al-Hikmah, 5(2), 56-67.

Setiawati, A.N, \& B.R. (2018). Pengaruh Pelatihan Komunikasi Interpersonal Terhadap Kohesivitas Kelompok pada Divisi Food and Beverage Product Hotel X Bintang 5 Yogyakarta. Jurnal Ilmiah Psikologi Terapan, 06, (01), 41-53.

Sukri. (2016). Keniscayaan konflik dalam masyarakat demokrasi. Jurnal Politik Profetik, 04, (2), 153-170.

Theaker, A. (2001). Public Relations Handbook. London: Routledge.

West, Richard, dan L. H. T. (2008). Pengantar Teori Komunikasi. 276.

Widia Prastyanti, E. (2017). Pengaruh pembagian kerja terhadap peningkatan efisiensi kerja karyawan pastry di hotel santika premiere malang. Pesona, 2, (02), 1-6.

Wijayanta, T. (2007). Perkembangan Perbedaan Pendapat (Dissenting Opinion) Dalam Putusan Kepailitan Di Pengadilan Niaga Jakarta Pusat. Mimbar Hukum, 19, (3), 335-485. https://doi.org/10.1017/ CBO9781107415324.004 